\title{
USE OF EVIDENCE OBTAINED IN BREACH OF THE CONVENTION RIGHTS AS A VIOLATION OF THE RIGHT TO A FAIR TRIAL
}

UDC 343.14:341.231.14

\author{
Darko Dimovski ${ }^{1}$, Petar Pešić \\ ${ }^{1}$ Faculty of Law, University of Niš, Republic of Serbia \\ ${ }^{2}$ Law Office Bončić, Niš, Republic of Serbia
}

\begin{abstract}
This paper focuses on the review of standards established by the European Court of Human Rights (ECtHR) with regards to the use of evidence obtained in breach of the rights set out in the European Convention on Human Rights and Fundamental Freedoms (ECHR), ultimately resulting in a violation of the right to a fair trial. Due consideration has been given to the use of evidence obtained in violation of Article 3, Article 8 and the privilege against self-incrimination. Even though the specific rules on admissibility of evidence were to be regulated by each of the Contracting States, the Court set out standards on the use of evidence in order to address the primary question: Does the use of evidence obtained in breach of the Convention rights render the proceedings as a whole to be unfair? The authors analyze the Court jurisprudence on this matter and the evolution of these standards over time in order to respond to this question.
\end{abstract}

Key words: right to a fair trial, use of evidence, breach of ECHR, torture evidence, privilege against self-incrimination

\section{INTRODUCTION}

Right to a fair trial is enshrined in Article 6 of the European Convention on Human Rights and Fundamental Freedoms (ECHR). ${ }^{1}$ As such, it covers a number of rights which were set out in order to guarantee fair trial proceedings (in criminal, civil and other cases), in full observance of the guaranteed procedural rights. It is one of the rights which have most

Received February 22 nd 2017 / Accepted July 6 ${ }^{\text {th }}, 2017$

Corresponding author: Assist. Prof. Darko Dimovski

Faculty of Law, University of Niš, Trg Kralja Aleksandra 11, 18000 Niš, Republic of Serbia

E-mail: darko.dimovski@yahoo.com

${ }^{1}$ The European Convention on Human Rights (adopted on 4 November 1950, entered into force 3 September 1953), Article 6 ECHR 
frequently been the subject matter of adjudication before the European Court of Human Rights (ECtHR). ${ }^{2}$ The Court's stance is that the Convention is intended to guarantee "not rights that are theoretical and illusory but rights that are practical and effective" (Hoyano, 2001: 948-969). However, looking at the Convention itself, the right to a fair trial embodies only certain limited guarantees which are covered in rather broad terms. The Court's task is to interpret the rights set out in the Convention, and apply them to cases referred to this Court. Hence, the Court took the stance that there may arise an issue under the right to a fair trial if illegal evidence was used in criminal proceedings against a person. Yet, in the wording of Article 6 of the Convention (right to a fair trial), there is no single reference to evidence; Article 6 (par. 1) ECHR states as follows:

"In the determination of his civil rights and obligations or of any criminal charge against him, everyone is entitled to a fair and public hearing within a reasonable time by an independent and impartial tribunal established by law. Judgment shall be pronounced publicly but the press and public may be excluded from all or part of the trial in the interests of morals, public order or national security in a democratic society, where the interests of juveniles or the protection of the private life of the parties so require, or to the extent strictly necessary in the opinion of the court in special circumstances where publicity would prejudice the interest of justice."

Therefore, there is no reference to evidence, either legally or illegally obtained, in Article 6 of the Convention. It does not come as a surprise given the fact that the wording of the Article 6 is basically taken from the International Covenant on Civil and Political Rights (ICCPR). ${ }^{3}$ Having in mind that these documents are international treaties which envisaged the general framework of fundamental human rights, it is not surprising that the use of illegal evidence (as a highly specific issue) is not covered by this right.

On the other hand, in applying the Convention, the Court recognized that the issue of fairness of proceedings may arise when the evidence obtained in breach of the Convention rights is used against the defendant. The Court established these standards to ensure that illegally obtained evidence would not infringe upon the right to a fair trial. By applying the concept of "the Convention as a living instrument, to be interpreted in the present-day conditions" ${ }^{\prime 4}$, the Court recognized that the use of illegal evidence may breach the fairness of court proceedings. This article deals with the standards established by the Court regarding the issue of fairness of proceedings which may be violated by using illegally obtained evidence.

\section{GENERAL PRINCIPLES SET OUT BY THE ECTHR}

The Court set out general principles governing fair proceedings when issues concerning the use of evidence arise. First of all, we should bear in mind Article 19 of the Convention which envisaged the establishment of the European Court of Human Rights, stating:

"To ensure the observance of the engagements undertaken by the High Contracting Parties in the Convention and the Protocols thereto, there shall be set up a European Court of Human Rights, hereinafter referred to as "the Court". It shall function on a permanent basis."

\footnotetext{
${ }^{2}$ Per HUDOC database, until $26^{\text {th }}$ January 2017, it has been decided 28,187 times.

${ }^{3}$ Compare: Article 6 of the European Convention on Human Rights and Fundamental Freedoms (1950) and Article 14 of the International Covenant on Civil and Political Rights (adopted 16 December 1966, entered into force 23 March 1976) 999 UNTS 171 (ICCPR).

${ }^{4}$ Case $X$ and others v. Austria, Application no. 19010/07
} 
Looking into this Article, we can conclude that the Court's duty is to observe the engagements undertaken by the Contracting States. As the Convention does not impose any obligations regarding the use of evidence in the proceedings, this matter was to be regulated by each Contracting State.

In its jurisprudence, the Court stated that the Convention set no rules on the admissibility of evidence.. ${ }^{5}$ In these circumstances, it is not the Court's duty to assess whether certain evidence should be declared admissible or not and, therefore, used in the proceedings. ${ }^{6}$ The Court should respond to the question whether the proceedings as a whole, including the way in which the evidence was obtained, were fair. ${ }^{7}$ In answering this question, the Court examines the "unlawfulness" in question and, where a violation of another right guaranteed under the Convention is concerned, the nature of the violation found. ${ }^{8}$ The Court also stated that the same standards apply irrespective of the legal system that is in force in the Contracting State. ${ }^{9}$

In determining whether the proceedings were fair, particular regard must be given to the rights of defence. ${ }^{10}$ In that respect, it is reviewed whether the applicant had the opportunity to challenge the authenticity of the evidence in question and oppose its reliability or accuracy. ${ }^{11}$ Additionally, the quality of the evidence is taken into consideration, and the circumstances in which the evidence was obtained and whether there are circumstances which cast doubt on the reliability or accuracy of the evidence in question. ${ }^{12}$ The Court states that the need for corresponding evidence is largely reduced in cases where the evidence is very strong and there is no risk of it being unreliable. ${ }^{13}$ The Court also takes into account whether the evidence in question was or was not decisive for the outcome of the proceedings. $^{14}$

When examining the nature of the alleged violation of the Convention, the Court repeatedly stated that if the information obtained in violation of Article 8 was used as evidence in court proceedings, the examination whether that rendered the trial as a whole to be unfair must include all the circumstances of the case, including respect for the defence rights and the quality and importance of the evidence in question. ${ }^{15}$ However, different standards are applied when the Court deals with evidence obtained in breach of Article 3 of the Convention (on prohibition of torture). Article 3 is an absolute right, which cannot be derogated. ${ }^{16}$ The use of evidence obtained in violation of Article 3 always raises serious issues regarding fairness of proceedings, even if the admission of such evidence was not decisive in securing a conviction. ${ }^{17}$ Therefore, the Court's stance is that the use of statements or confessions which were given as a result of torture or other ill-treatment in breach of

\footnotetext{
${ }^{5}$ Case Schenk v. Switzerland, Ap. 10862/84; Case Heglas v. The Czech Republic Ap. 5935/02

${ }^{6}$ Case Khan v. The United Kingdom, Ap. 35394/97; Case P.G. and J.H. v. The United Kingdom, Ap. 44787/98; Case Allan v. The United Kingdom, Ap. 48539/99

${ }^{7}$ Case Jalloh v. Germany, Ap. 54810/00

${ }^{8}$ Case Gäfgen v. Germany, Ap. 22978/05

${ }^{9}$ Case Al-Khawaja and Tahery v. The United Kingdom [GC], Ap. 26766/05 and Ap. 22228/06

${ }^{10}$ Case Al-Khawaja and Tahery v. The United Kingdom [GC], Ap. 26766/05 and Ap. 22228/06

${ }^{11}$ Case Al-Khawaja and Tahery v. The United Kingdom [GC], Ap. 26766/05 and Ap. 22228/06

${ }^{12}$ Case Al-Khawaja and Tahery v. The United Kingdom [GC], Ap. 26766/05 and Ap. 22228/06

${ }^{13}$ Case Allan v. The United Kingdom, Ap. 48539/99

${ }^{14}$ Case Khan v. The United Kingdom, Ap. 35394/97

${ }^{15}$ Case Bykov v. Russia [GC], Ap. 4378/08

${ }^{16}$ Case Selmouni v. France [GC], Ap. 25803/94

${ }^{17}$ Case Í Içöz v. Turkey (dec.), Ap. 54919/00
} 
Article 3 renders the proceedings as a whole to be unfair. ${ }^{18}$ This marks the first red line set out by the Court.

A slightly less stringent line has been set when it comes to the use of real evidence obtained as a result of torture. The Court takes the stance that such evidence should never be relied on as proof of the victim's guilt, irrespective of its probative value. ${ }^{19}$ It is worth noting that the Court sees that all other views of this problem would "afford brutality the cloak of law" 20 . Such stance of the Court is supported by the United Nations Convention against Torture and Other Cruel, Inhuman or Degrading Treatment or Punishment, which provides (in Article 15) that statements which are established to have been made as a result of torture shall not be used in evidence in proceedings against the victim of torture. The line is even less strict when the treatment in question is qualified as inhuman and degrading, but falling short of torture. In order to assess whether the use of evidence obtained through inhuman and degrading treatment renders proceedings to be unfair, the Court takes into account certain factors. Those factors are weight attached to the evidence, its probative value and the opportunities of the defendant to challenge its admission and use at trial. ${ }^{21}$

The Court has also dealt with issues concerning the use of evidence obtained in breach of the right to remain silent and the privilege against self-incrimination. These guarantees are generally recognized international standards and present the heart of the notion of fair procedures under Article $6 .{ }^{22}$ The right not to incriminate oneself presupposes that the prosecution authorities in a criminal case seek to prove their case against the accused without resorting to evidence obtained through methods of coercion or oppression in defiance of the will of the accused. ${ }^{23}$

Additionally, the Court has reviewed cases involving other types of evidence. For example, the use of evidence obtained through police informant may infringe the right to a fair trial. The Court stated that all evidence obtained as a result of police incitement to commit crimes must be excluded from being used in the proceedings. ${ }^{24}$ If national courts could not conclude whether there had been an incitement to commit crimes, based on the information provided by the prosecution authorities, there should be a careful assessment of plea of incitement guaranteeing respect for the rights of defence, in particular the right to adversarial proceedings and to equality of arms. ${ }^{25}$ The Court also examined the use of statements obtained without the presence of a lawyer at trial and found breaches of the right to a fair trial (Hadgon, 2011). ${ }^{26}$

Issues relating to the use of illegally obtained evidence may arise under Article 6 in cases involving extradition or expulsion of a person to another country in order to stand trial. One of the most notable cases relating to the use of evidence contrary to the Convention in extradition or expulsion matters is the case of Othman (Abu Qatada). The Court previously stated that right to a fair trial may be infringed if the fugitive suffered or risked suffering a "flagrant denial of justice". ${ }^{27}$ The question that arose in the case of Othman is whether the use of

\footnotetext{
${ }^{18}$ Case Örs and Others v. Turkey, Ap. 46213/99; Case Söylemez v. Turkey, Ap. 46661/99

${ }^{19}$ Case Jalloh v. Germany. Ap. 54810/00

${ }^{20}$ Case Rochin v. California, 342 U.S. 165 (1952)

${ }^{21}$ Case Jalloh v. Germany, Ap. 54810/00

${ }^{22}$ Case Saunders v. The United Kingdom [GC], Ap. 19187/91

${ }^{23}$ Case Heaney and McGuinness v. Ireland, Ap. 34720/97

${ }^{24}$ Case Ramanauskas v. Lithuania, Ap. 74420/01

${ }^{25}$ Case Edwards and Lewis v. The United Kingdom [GC] Ap. $39647 / 98$ and Ap. 40461/98

${ }^{26}$ Case Sebalj v. Croatia, Ap. 4429/09;

${ }^{27}$ Case Soering v. The United Kingdom, Ap. 14038/88
} 
evidence obtained in violation of Article 3 (i.e. through the use of torture) may represent a "flagrant denial of justice" and thus constitute a violation of the right to a fair trial. Having in mind the standards in international law and its jurisprudence, the Court vehemently opposed the use of evidence obtained through torture stating that such practice represents a "flagrant denial of justice" and is contrary to the right to a fair trial (Jackson, 2016: 1-17). However, to conclude whether there is a violation of the right to a fair trial if the applicant is to be extradited or expelled, the Court must examine whether there is a "real risk" of using the evidence obtained through torture, and whether or not the rights of defence would be respected in the course of proceedings. Only then, the Court may reach a conclusion on whether there has been a violation of the right to a fair trial.

These are the general standards that have been set by the Court and observed in the process of reviewing the cases referred to the Court.

\section{THE APPLICATION OF THESE PRINCIPLES IN CASE LAW}

\subsection{Use of evidence obtained in breach of Article 3}

As stated earlier, the use of evidence obtained in breach of Article 3 always raises serious questions regarding the fairness of proceedings. Depending of the treatment in question, standards set by the Court could be regarded as more or less stringent. The most stringent requirements are set by the Court in cases relating to the use of evidence obtained through torture. It is to be expected that if such evidence was used in the proceedings against the applicant, there would be a violation of the right to a fair trial as torture is in contravention with the aim of the Convention and international law in general.

However, when the treatment in question does not constitute torture but is regarded as inhuman and/or degrading treatment, things are not so smooth. In the landmark Gäfgen case, the Court examined the issue of the use of evidence obtained as a result of inhuman and degrading treatment applied to the applicant in that case. The Court stated that the right to fair trial may be breached if the use of evidence obtained in breach of Article 3 had impact on the defendant's conviction or sentence. ${ }^{28}$ Therefore, there has to be a causal link between the prohibited treatment and the conviction and sentence in respect of the impugned evidence. If that link is broken by additional evidence, then the impact of the impugned evidence on the conviction and sentence of the applicant is reduced. The Court considers it necessary for national courts to restore or make an attempt to restore the situation in the proceedings as it was before the treatment in breach of Article 3 occurred. ${ }^{29}$ Thereby, national courts would show their willingness to shed light on the events in question and reach conclusion having gathered all the facts of the case. Furthermore, the applicant should have a remedy to challenge the admission of evidence he or she finds to be obtained through prohibited treatment. ${ }^{30}$ There is only a need for a legal remedy to challenge the admission of such evidence. The Court does not oblige States to exclude evidence which was challenged by the applicant during the proceedings. An additional factor is the public interest in securing the conviction. ${ }^{31}$ When it comes to

\footnotetext{
${ }^{28}$ Case Gäfgen v. Germany, Ap. 22978/05

${ }^{29}$ Case Gäfgen v. Germany, Ap. 22978/05

${ }^{30}$ Case Gäfgen v. Germany, Ap. 22978/05

${ }^{31}$ Case Jalloh v. Germany, Ap. 54810/00
} 
assessing the public interest, the level of danger posed or created by the committed offence is taken into account.

In the El Haski case, ${ }^{32}$ the Court clarified its stance on the use of evidence obtained through treatment contrary to Article 3. The Court stated that the use of statements obtained through treatment which is contrary to Article 3 , no matter if it is qualified as torture, inhuman and/or degrading treatment, would render proceedings to be unfair as a whole. On the other hand, if real evidence is obtained through treatment contrary to Article 3, standards are a little bit different. If the treatment in question amounts to torture, then the use of real evidence always renders proceedings unfair as a whole. ${ }^{33}$ When the treatment is qualified as inhuman and/or degrading treatment, the Court decides if the proceedings are unfair if the use of such evidence had influence on the outcome of the proceedings. ${ }^{34}$ It is to be noted that, in the El Haski case, the Court decided that if "real risk" that the evidence obtained through treatment which is contrary to Article 3 persists, and national courts did not take steps to ensure that there was no such treatment in obtaining evidence, the proceedings were unfair as a whole and consequently resulted in a violation of Article $6 .{ }^{35}$

\subsection{Differing views}

In the landmark cases Jalloh and Gäfgen, we can find differing views of the Court judges on the use of evidence obtained in breach of Article 3. The common stance, given in the partly dissenting opinion of six judges in the Gäfgen case ${ }^{36}$ and the concurring opinion of judge Bratza in the Jalloh case $^{37}$, is that there should be a violation of the right to a fair trial in all cases where the evidence obtained in breach of Article 3 was used in the proceedings. Judge Bratza unequivocally noted:

"The use of evidence obtained by treatment violating the fundamental values enshrined in Article 3 appears to me to offend against the whole concept of a fair trial, even if the admission of such evidence is not - as it was in the present case - decisive in securing a conviction. As in the case of the use of coerced confessions, it is the offensiveness to civilised values of fairness and the detrimental effect on the integrity of the judicial process, as much as the unreliability of any evidence which may be obtained, which lies at the heart of the objection to its use."

It seems there is a point in the judges' reasoning. If Article 3 is an absolute right, which shall not to be derogated at any time, then there should not be different standards depending on the qualification of the treatment in question.

Furthermore, the presence of the formerly mentioned causal link is seen as unnecessary. Proceedings are an organic whole, and should not be parsed in order to conclude that the use of illegally obtained evidence constituted a violation of the right to a fair trial. Due regard should be given to the fact that the defendant's defence is based on the admitted evidence, and that the use of such evidence at any point during the trial may have irreversible effects and restricts the defendant's freedom to mount a defence.

\footnotetext{
${ }^{32}$ Case El Haski v. Belgium, Ap. 649/08

${ }^{33}$ Case El Haski v. Belgium, Ap. 649/08

${ }^{34}$ Case El Haski v. Belgium, Ap. 649/08

${ }^{35}$ Case El Haski v. Belgium, Ap. 649/08

${ }^{36}$ Case Gäfgen v. Germany, Ap. 22978/05

${ }^{37}$ Case Jalloh v. Germany, Ap. 54810/00
} 
Judge Bratza stated that the public interest should not have any bearings on the outcome of the examination of issues pertaining to the fairness of proceedings. This opinion constitutes a proper assessment of the principles enshrined in the Convention. Taking into account the public interest would undermine the absolute nature of Article 3; moreover, it would suggest to national authorities that they could get away with evidence obtained through treatment contrary to Article 3 in case such evidence is used in the proceedings for less serious offences.

\subsection{Use of evidence obtained in violation of Article 8}

When examining the use of evidence obtained in breach of Article 8, the Court takes into account the circumstances of the case at issue. Particular consideration is given to balancing the protection of public safety and preventing the misuse of government power (Kerr, 2005: 531; Fura, Klamberg, 2012: 463-481). The line which divides situations resulting in violation of the right to a fair trial and those that had the opposite result is more blurry and depends on assessing the circumstances in each case. In the landmark case of $S$ chenk $^{38}$, the Court singled out two factors which are important for examination of whether the use of evidence obtained in breach of Article 8 deprived the applicant of the right to a fair trial. These two factors are:

1) possibility to challenge the admission of evidence in question;

2) whether there was other evidence on which the conviction was based.

These factors were mentioned earlier, but here they form an integral part of the assessment as Article 8 is not an absolute right and a restriction of rights guaranteed by it may exist if certain conditions are fulfilled.

Once again, the possibility to challenge the admission of evidence needs to exist. If the applicant made an attempt to challenge the admission of evidence and was unsuccessful in that pursuit, it makes no difference in the eyes of the Court.

As far as the second criteria from the Schenk case is concerned, the Court departed from this standard in the case of $\mathrm{Khan}^{39}$. In that case, the evidence which was obtained contrary to Article 8 was the only evidence against the applicant; moreover, it was very strong evidence which formed the basis for the conviction. However, the Court concluded that there was no violation of right to a fair trial because the applicant had the possibility to challenge the use of such evidence and that national courts could have excluded it if they were of the opinion that it would give rise to substantive unfairness. In essence, we can state that the most important factor is whether or not there was a possibility to challenge the admission of evidence obtained contrary to Article 8.

\subsection{Use of evidence obtained in violation of privilege against self-incrimination}

The defendant's right to remain silent is one of most universally recognized guarantees in the criminal proceedings (Berger, 2006: 340). ${ }^{40}$ Although it is protected by the Convention, this right can be violated in three ways identified by the Court: first, if the national authorities apply physical or psychological pressure on the accused in order to obtain statements or evidence, ${ }^{41}$ second, in case a suspect is obliged to testify under threat of sanctions and either

\footnotetext{
${ }^{38}$ Case Schenk v. Switzerland, Ap. 10862/84

${ }^{39}$ Case Khan v. The United Kingdom, Ap. 35394/97

${ }^{40}$ Orkem SA, formerly CDF Chimie SA v. Commission of the European Communities, 1989 E.C.R. 3289, § 111

${ }^{41}$ Case Magee v. The United Kingdom, Ap. 28135/95
} 
testifies in consequence ${ }^{42}$ or is sanctioned for refusing to testify; ${ }^{43}$ and third, in case the authorities use subterfuge to elicit information that they were unable to obtain during questioning. ${ }^{44}$ However, in order for compulsion on the accused to violate his right against self-incrimination, such compulsion shall be of such magnitude that it destroys the very essence of the said right. ${ }^{45}$ The important factor is the use to which evidence obtained under compulsion is put in the course of the criminal trial. ${ }^{46}$ For the fairness assessment, the Court in the case of Ibrahim and others made a non-exhaustive list of factors which should be taken into account where it is appropriate. The list includes the following factors:

(a) Whether the applicant was particularly vulnerable, for example, by reason of his age or mental capacity.

(b) The legal framework governing the pre-trial proceedings and the admissibility of evidence at trial, and whether it was complied with; where an exclusionary rule applied, it is particularly unlikely that the proceedings as a whole would be considered unfair.

(c) Whether the applicant had the opportunity to challenge the authenticity of the evidence and oppose its use.

(d) The quality of the evidence and whether the circumstances in which it was obtained cast doubt on its reliability or accuracy, taking into account the degree and nature of any compulsion.

(e) Where evidence was obtained unlawfully, the unlawfulness in question and, where it stems from a violation of another Convention Article, the nature of the violation found.

(f) In case of a statement, the nature of the statement and whether it was promptly retracted or modified.

(g) The use to which the evidence was put, and in particular whether the evidence formed an integral or significant part of the probative evidence upon which the conviction was based, and the strength of the other evidence in the case.

(h) Whether the assessment of guilt was performed by professional judges or lay jurors and, in the case of the latter, the content of any jury directions.

(i) The weight of the public interest in the investigation and punishment of the particular offence at issue.

(j) Other relevant procedural safeguards afforded by domestic law and practice.

In majority of cases, the Court is most unlikely to examine all the factors from the list. However, certain cases would require a thorough assessment and, thus, it is likely that these and maybe some other factors would be taken into account in examining whether there has been a violation of the right to a fair trial or not.

\section{CONCLUSION}

Having examined the jurisprudence of the Court and the standards applied in the cases involving examination on the use of evidence obtained in breach of Convention rights and the issues pertaining to the fairness of proceedings, we can conclude that the Court's

\footnotetext{
${ }^{42}$ Case Brusco v. France, Ap. 1466/07

${ }^{43}$ Case Weh v. Austria, Ap. 38544/97

${ }^{44}$ Case Allan v. The United Kingdom, Ap. $48539 / 99$

${ }^{45}$ Case John Murray v. The United Kingdom, Ap. 18371/91

${ }^{46}$ Case Saunders v. The United Kingdom [GC], Ap. 19187/91
} 
stance is in most cases foreseeable. A firm stance on the use of evidence obtained through torture is in conformity with internationally adopted standards relating to the prohibition of torture. As for use of evidence obtained through inhuman and/or degrading treatment, the Court makes a distinction between statements and real evidence obtained in such manner. The use of statements renders proceedings unfair as a whole, while the use of real evidence does not automatically triggers unfairness of the proceedings. The examination of case circumstances and the effect that the use of evidence obtained through inhuman and/or degrading treatment had on the outcome of the proceedings is required.

The Court's stance is less stringent in cases involving the use of evidence obtained through violation of Article 8. The Court takes into account whether there was a possibility to challenge the admission of such evidence, regardless of the results of such challenge; in certain cases, the Court examines whether there was additional evidence that formed a basis for conviction and sentence.

When examining the use of evidence obtained through violation of privilege against self-incrimination, the Court generally does not allow the use of evidence obtained through coercion and oppression. However, coercion and oppression must be of such magnitude to destroy the very essence of the privilege against self-incrimination. In its jurisprudence, the Court has come up with a non-exhaustive list of factors which should be examined to conclude whether or not proceedings were unfair as a whole. Based on the circumstances of each case, the Court decides which factors should be taken into account.

To conclude, the use of evidence obtained through violation of the Convention rights raises issues concerning the fairness of the proceedings. National courts should be more careful when deciding if such evidence should be admitted or not. In line with the Court jurisprudence, new applications to the Court may be prevented if national courts follow the set standards and make a thorough assessment of the circumstances of each case.

\section{REFERENCES}

European Law, Vol. 12, 2006, p.340;

Fura E., Klamberg M., (2012), The Chilling Effect of Counter-Terrorism Measures: A Comparative Analysis of Electronic Surveillance Laws in Europe and the USA, In: Casadevall J., Myjer E., O'Boyle M.(ed), Freedom of Expression: Essays in honour of Nicolas Bratza - President of the European Court of Human Rights, Oisterwijk, 2012, pp. 463-481

Hodgon J., (2011), Safeguarding Suspects' Rights in Europe: A Comparative Perspective, In: New Criminal Law Review, Vol. 14, No. 4, 2011

Hoyano C. H. L., (2001) Striking the balance between the rights of defendants and vulnerable witnesses: Will special measures directions contravene the right to a fair trial?, Criminal Law Review-London, 2001, pp. 948-969

Jackson M., (2016), Freeing Soering: The ECHR, State Complicity in Torture, and Jurisdiction, European Journal of International Law, Vol. 27, No. 3, 2016, pp 1-17

Kerr, Orin S., (2005), Searches and Seizures in a Digital World, Harvard Law Review, Vol. 119, No. 2, 2005, p. 531

Treaties

The European Convention on Human Rights (adopted 4 November 1950, entered into force 3 September 1953) (ECHR)

The International Covenant on Civil and Political Rights (adopted 16 December 1966, entered into force 23 March 1976) 999 UNTS 171 (ICCPR) 
Internet sources

HUDOC database - http://hudoc.echr.coe.int

List of cases

1. Schenk v. Switzerland, Ap. no.10862/84

2. Soering v. The United Kingdom, Ap. 14038/88

3. Brusco v. France, Ap. 1466/07

4. John Murray v. The United Kingdom, Ap. 18371/91

5. X and others v. Austria, Ap. 19010/07

6. Saunders v. The United Kingdom [GC], Ap. $19187 / 91$

7. Gäfgen v. Germany, Ap. 22978/05

8. Selmouni v. France [GC], Ap. 25803/94

9. Al-Khawaja and Tahery v. The United Kingdom [GC], Ap. 26766/05 and Ap. 22228/06

10. Magee v. The United Kingdom, Ap. 28135/95

11. Heaney and McGuinness v. Ireland, Ap. $34720 / 97$

12. Khan v. The United Kingdom, Ap. 35394/97

13. Weh v. Austria Case, Ap. 38544/97

14. Edwards and Lewis v. The United Kingdom [GC], Ap. $39647 / 98$ and Ap. $40461 / 98$

15. Bykov v. Russia [GC], Ap. 4378/08

16. Sebalj v. Croatia, Case Ap. $4429 / 09$

17. P.G. and J.H. v. The United Kingdom, Ap. $44787 / 98$

18. Örs and Others v. Turkey, Ap. 46213/99

19. Söylemez v. Turkey, Case Ap. 46661/99

20. Allan v. The United Kingdom, Ap. 48539/99

21. Jalloh v. Germany, Case Ap. $54810 / 00$

22. İçöz v. Turkey (dec.), Ap. 54919/00

23. Heglas v. The Czech Republic, Ap. 5935/02

24. El Haski v. Belgium, Ap. 649/08

25. Ramanauskas v. Lithuania, Ap. 74420/01

26. Orkem SA, formerly CDF Chimie SA v. Commission of the European Communities, 1989 E.C.R. 3289, § 111

27. Rochin v. California, 342 U.S. 165 (1952)

\section{UPOTREBA DOKAZA PRIBAVLJENIH PROTIVNO PRAVIMA IZ KONVENCIJE PREDSTAVLJA POVREDU PRAVA NA PRAVIČNO SUĐENJE}

Ovaj rad se bavi analizom standarda uspostavljenih od strane Evropskog suda za ljudska prava u pogledu upotrebe dokaza pribavljenih kršenjem prava garantovanih Evropskom konvencijom o ljudskim pravima i osnovnim slobodama, što dovodi do povrede prava na pravično suđenje. Poseban osvrt je dat na upotrebu dokaza pribavljenih kršenjem člana 3, člana 8 i prava protiv samoinkriminacije. Iako su pravila vezana za prihvatljivost dokaza u nadležnosti država potpisnica Konvencije, Sud je postavio određene standarde kako bi se dao odgovor na pitanje: da li upotreba dokaza pribavljenih kršenjem prava iz Konvencije dovodi do nepravičnosti celokupnog postupka? U pokušaju da odgovore na ovo pitanje, autori su analizirali praksu Suda i evoluciju ovih standarda.

Ključne reči: pravo na pravnično suđenje, upotreba dokaza pribavljenih protivno Konvenciji, dokazi pribavljeni mučenjem, pravo protiv samoinkriminacije 